\title{
LEGAL PROTECTION OF THE COMPANY NAME AND GEOGRAPHICAL INDICATION AS MARKETING DESIGNATIONS
}

\section{Mazurenko S. V.}

\section{INTRODUCTION}

Development of market relations, intensification of business activity, expansion of the sphere and volumes of material production, changes in the socio-economic structure of the state led to the introduction of market mechanisms in the economy of Ukraine, the manifestation of which was the intensification of competition between economic entities operating in one or related industries. Under the influence of these factors, the importance and role of the special identifying marks used by manufacturers to distinguish themselves and the results of their activity means of individualizing the participants of the civil turnover, goods and services, grows. Due to changes in the economic sphere, there is a need to develop and implement adequate legal mechanisms for regulating relationships related to the use and reliable protection of business names, trademarks and geographical indications.

The following intellectual property rights are included in the means of individualization of the participants of the civil turnover, goods and services: commercial (trade name); trademark (trademark, sign for goods and services); geographical indication (indication of origin of goods). Therefore, the trademark, trade name and indication of origin of the goods form a separate group of intellectual property rights, which are traditionally referred to as "means of individualization" or "commercial (marketing) designation". The use of these objects ensures the individualization, identification of the business entity and its products in market relations. These distinctive designations are a manifestation of individualization, which is broadly understood as empowering individuals with distinctive features that distinguish them from other persons with whom they participate in legal relationships.

The value of the means of individualization in the conditions of development of competitive relations, increasing the variety of organizational and legal forms of economic activity, expansion of international economic ties necessitates the proper legal regulation of subjective rights, which mediate the performance of these objects of their functions and ensure the satisfaction of the interests of its subjects. 


\section{Intellectual property right to the company name}

When studying this topic, it should be noted that the term "commercial name" was first introduced into the legislation of Ukraine by the Central Committee of Ukraine. Prior to the adoption of the Central Committee of Ukraine, two terms were used: "corporate name" and "corporate name". The only act that contained rules on the use of company names was the resolution of the Central Executive Committee of the USSR and the Council of People's Commissars of 22.06.1927 "On the enactment of the Regulations on the firm" (as amended), which determined the legal basis of the activities of firms of different organizational - legal forms. According to the letter of the Supreme Economic Court of Ukraine of January 14, 2004 No. 05-3 / 31 in connection with the adoption of the Civil Code of Ukraine and the Civil Code of Ukraine, which regulates the issue of intellectual property right to a commercial name, from January 1, 2004 in Ukraine the stated Company Regulations apply. Despite the adoption of these codes, business names are one of the few entities whose legal regime still requires legislative improvement. Unlike most other intellectual property (trademarks, industrial designs, inventions, utility models, copyright and related rights), the legal regulation of commercial names is not governed by any special laws. Although some references to commercial names are contained in some regulatory acts of Ukraine, in particular in the Criminal Code of Ukraine, the Law of Ukraine "On Protection of Rights to Marks for Goods and Services", the Law of Ukraine "On Protection against Unfair Competition", etc. ${ }^{1}$

Pursuant to the Paris Convention for the Protection of Industrial Property of 20 March 1883, trade names are objects of industrial property. Commercial names, along with trademarks and geographical indications, are means of individualizing participants in civilian traffic, goods and services. In determining the structure of the business name, the following should be noted. There are two parts of the company: the main (corpus of the firm) and the subsidiary (arbitrary) ${ }^{2}$.

The corpus of the firm is a mandatory part of the commercial (corporate name), contains an indication of the legal form of the enterprise, its type and subject of activity, and in some cases, other characteristics. For example, the name of the full partnership, in addition to the indication of the legal form -

${ }^{1}$ Коссак В.М., Якубівський І.Є. Право інтелектуальної власності: підручник. К. : Істина, 2007. С. 78.

2 Козлова О., Ковач Ж. Деякі проблеми правового регулювання комерційних найменувань в Україні у контексті міжнародно-правового досвіду // Промислова власність в Україні: проблеми правової охорони: зб. наук. статей /за ред. Ю.С. Шемшученка, Ю.Л. Бошицького. К.: Ін-т держави і права ім. В.М. Корецького НАН України, 2004. C. 326 . 
"full partnership", must also include the names (name) of all participants or the name (name) of one or more of them with the addition of the words "and company" (Art. 119 CC Ukraine). And the commercial name of a joint stock company should indicate that the company is a joint stock company (Article 152 of the Civil Code of Ukraine) ${ }^{3}$.

The auxiliary part is made up of mandatory and optional elements. A custom business name is a required part of the business name auxiliary. It can be any word, proper name, geographical name, etc. Optional elements are included in the trade name at the request of the owner. These include the abbreviated name of the company, instructions such as "specialized", "central", "universal", including the abbreviated name of the company (KAMAZ, ZIL, etc.). However, these applications should also be untrue and misleading. Exceptions are full and limited partnerships, in the auxiliary part of the name of which must be the names of all full members of the company or the name (name) of at least one full participant with the words "and company", as well as the words "full partnership", or a limited partnership, respectively ${ }^{4}$.

Legal protection is subject to both the full and abbreviated commercial name of an entity, if it is actually used by it in business. Article 489 of the Civil Code of Ukraine provides for two conditions for obtaining legal protection. First, the business name must make it possible to distinguish one person from the other. That is, to perform a dystopian function.

Secondly, the commercial name of a person should not mislead consumers as to their true activity. That is, perform a safety function. Individuals may have the same business name if it does not mislead consumers as to the goods they produce and (or) sell and the services they provide.

In addition, some scholars also highlight the condition of novelty and invariance of the commercial name.

Ievina OV, Mironenko VP, Pavlovskaya NV and Pilipenko S.A. also distinguish the principles of commercial name:

- truthfulness - to accurately reflect the legal status and not to mislead other members of the civil turnover;

- exclusivity - a certain originality of the name, the presence of distinguishing features, due to which it is not allowed to mix one firm with another;

\footnotetext{
${ }^{3}$ Сергеев А.П. Право интеллектуальной собственности. М. : Теис, 1996. С. 524.

4 Козлова О., Ковач Ж. Деякі проблеми правового регулювання комерційних найменувань в Україні у контексті міжнародно-правового досвіду // Промислова власність в Україні: проблеми правової охорони: зб. наук. статей / за ред. Ю.С. Шемшученка, Ю.Л. Бошицького. К.: Ін-т держави і права ім. В.М. Корецького НАН України, 2004. C. 326.
} 
- Continuity - The name of a particular subject is retained over a long period of time.

Palladiy MV draws attention to the fact that the business name performs mainly two functions: distin- guish, that is, distinguishes one participant of commercial activity from another regardless of what goods or services they sell and market, and preventive, ie does not give mislead consumers about its true activity ${ }^{5}$.

In addition, some scientists distinguish between security, advertising, warranty functions. Due to the lack of sufficient legal regulation of business names, there are currently many issues in Ukraine that are the subject of heated debate among Ukrainian intellectual property professionals.

Discussions are underway over the subjects of the trade name rights. The Civil Code of Ukraine uses the term "persons", which, based on the content of Section II of the Book of the First Civil Code of Ukraine, may be used to refer to both legal entities and individuals, including entrepreneurs. Thus in Art. 90 of the Civil Code of Ukraine contains a restriction on the fact that commercial names can only be owned by business companies. Businesses for profit and subsequent distribution between participants (business partnerships) can only be created as business partnerships (full partnerships, limited partnerships, limited or additional partnerships, joint stock companies) or production cooperatives. The current jurisprudence in commercial courts is based on this particular restriction. Thus, item 4 of the Review Letter of the Supreme Economic Court of Ukraine "On the Practice of Application by the Commercial Courts of the Law on Protection of Intellectual Property Rights" dated 14.12.2007 No. 01-8 / 974 refers to the case on the claim of the Bar Association unity on the prohibition of a business entity - an individual to use in his activity in the field of law the sign "Legal consultation", which with reference to the provisions of Articles 16, 23, 50, 51, 90, 431, 432, 489-491 of the Civil Code of Ukraine the need to protect his commercial rights no name. The claim was upheld with reference to the fact that, in accordance with the first paragraph of the second part of Article 90 of the Civil Code of Ukraine, a commercial (company) name may have a legal entity, which is an entrepreneurial company.

According to Article 42 of the Civil Code of Ukraine, entrepreneurship is an independent, initiative, systematic, at-risk economic activity carried out by economic entities (entrepreneurs) in order to achieve economic and social

5 Паладій М.В. Право інтелектуальної власності на комерційне найменування // Правова охорона комерційних позначень в Україні: проблеми теорії і практики: зб. наук. статей / за заг. ред. Ю. С. Шемшученка, Ю.Л. Бошицького. К. : Ін-т держави і права ім. В.М. Корецького НАН України, 2006. С. 372. 
results and profit. At the same time, according to the provisions of Article 1 of the Law of Ukraine "On the Bar", the Bar of Ukraine is a voluntary professional public association, called in accordance with the Constitution of Ukraine to promote the protection of rights, freedoms and represent the legitimate interests of citizens of Ukraine, foreign citizens, stateless persons, legal entities give them other legal assistance. According to clause 2.1 of the statute of the plaintiff, registered with the Ministry of Justice of Ukraine to comply with the provisions of Article 4 of the Law of Ukraine "On the Bar", the purpose of the law association is to create the most favorable conditions for the successful work of the partner lawyers, to promote the development of a democratic rule of law, the protection of internationally recognized human rights and freedoms, the establishment of market relations in Ukraine. That is, the court found that the plaintiff, not being an entrepreneurial company, is not a subject of intellectual property rights to the business name.

The position of the Supreme Economic Court on the resolution of certain issues of protection of intellectual property rights to commercial names is also set out in the Review Letter of 01.04.2006 No. 01-8 / 845 "On the Practice of Application by the Commercial Courts of Law on the Protection of Ownership of Commercial Names (According to Case Files, considered in cassation by the Supreme Economic Court of Ukraine).

Civil Code of Ukraine Art. 159 establishes that the rights to a business name may belong only to economic entities, that is to say, legal entities and entrepreneurs. In doing so, the surname or first name may be claimed as a commercial designation by the citizen.

The issue of including a legal entity's legal form in the commercial name is also undefined. The business name of the business entity may be entered upon its submission to the registers, the procedure of which is prescribed by law. There is no special register of commercial names in Ukraine yet. To date, the use of business names has in fact been reduced to the use of legal entity names entered in the Unified State Register of Legal Entities and Entrepreneurs under the Law of Ukraine "On State Registration of Legal Entities and Entrepreneurs" of May 15, 2003. However as seen from Art. 90 of the Civil Code of Ukraine, the name of the legal entity and the commercial name are different legal categories. Yes, the name of the legal entity is the duty of the legal entity, and the commercial name is the right of the company. An entity with a business name previously entered in the register shall have priority over any other entity with the same business name later included in the register.

Content of intellectual property rights to the business name. Article 8 of the Paris Convention establishes that the trade name is protected in all the countries of the Union without compulsory application or registration and 
regardless of whether it is part of the trade mark. This is fully consistent with the provisions of Art. 489 of the Civil Code of Ukraine, according to which the intellectual property right for the commercial name is protected without the obligatory application for it or its registration and regardless of whether or not the commercial name is part of the trademark. If the business name of the entity is an element of its trademark, then the legal protection of both the business name and the trademark is exercised.

Under the proprietary rights of the intellectual property to the commercial name it is accepted to understand the rights of the participants of the civil turnover to own, use and dispose of the rights to the commercial name during the exercise of the person's activity. The essence of these property rights is that a person is guaranteed the opportunity to speak in civil turnover under his own business name and to protect his rights in due course.

According to Art. 490 of the Civil Code of Ukraine the intellectual property rights to the commercial name are:

- the right to use a business name;

- the right to prevent other persons from misusing the business name, including prohibiting such use;

- other intellectual property rights established by law.

These property rights can be exercised in various forms, in particular during the conclusion of civil agreements, the offering of goods (services) for sale, the protection of violated rights, the implementation of other legal actions. Commercial names can be used by placing them in business records, advertising, the Internet, goods, packaging, signboards, labels and more.

Misuse of another's business name is not permitted. Such actions are recognized by the current legislation of Ukraine as unfair competition. According to Art. 20 of the Law of Ukraine "On Protection against Unfair Competition" committing actions defined by this Law as unfair competition entails the imposition of penalties in due course by the Antimonopoly Committee of Ukraine, as well as administrative, civil and criminal liability. The offender may be prosecuted in accordance with Art. 512 of the Code of Ukraine on Administrative Offenses. Article 229 of the Criminal Code of Ukraine provides for the possibility of conviction of a guilty person to criminal liability on condition of causing material damage in large and large amounts. In this case, material damage is considered to be caused to a considerable extent if its size is twenty times more than the taxable minimum of citizens 'incomes, to a large extent - if its size is two hundred or more times the taxable minimum of citizens' incomes, and to a particularly large amount - if its size is a thousand times more than the taxable minimum income of citizens. 
A person whose trade name rights have been infringed may also go to court to defend his rights in civil law. A person who uses a different business name, at the request of his right holder, is obliged to discontinue such use and to recover damages. The use in the business name of the natural person's own name is not recognized as improper if any distinctive element is added to the personal name, which excludes confusion with the activity of another business entity (entrepreneur).

The trade name rights are valid from the first use and are valid indefinitely. Termination of intellectual property rights to a business name. Given that the intellectual property rights to the commercial name belong to the inalienable rights, their validity is terminated together with the termination of the activity of the person, in particular in case of liquidation of the legal entity. Although the list of grounds for termination of intellectual property rights to a commercial name is given in Art. 491 of the Civil Code of Ukraine is not exhaustive, so far the legislation of Ukraine contains no other grounds for this.

Intellectual property rights to a trade name may be transferred to another person only together with the whole property complex of the person to whom these rights belong, or a corresponding part thereof. The transfer of the whole property complex is carried out by the person to whom these rights belong on the basis of civil agreements. The transfer of the whole property complex can also be carried out in the order of sale of the debtor's property in the process of rehabilitation. According to Art. 19 of the Law of Ukraine "On restoration of the debtor's solvency or bankruptcy" in order to restore the solvency and satisfy the requirements of the debtor's creditors, the rehabilitation plan may provide for the sale of non-state debtor's property as a complete property complex. When selling a property of a non-state property debtor as a complete property complex, all types of property intended for the debtor's business activities, including premises, structures, equipment, inventory, raw materials, products, claims, rights to signs (designations) are alienated in due course. individuating the debtor, his products (works, services) (company name, marks for goods and services), other rights that belong to the debtor, except for rights and duties that cannot be transferred to other persons.

\section{Intellectual property right to the geographical indication of the place of origin of the goods}

Geographical indications are a means of individualizing goods. At the international level, a fairly extensive and effective system of legal protection of geographical indications has already been established and is operating. These issues are, in particular, governed by the Agreement on Trade-Related Aspects of Intellectual Property Rights signed by the World Trade Organization, the Paris Convention for the Protection of Industrial Property of 
20 March 1883, the Madrid Agreement to Prevent False or False Indications of the Origin of Goods, 18 The Lisbon Treaty for the Protection of Place Names and Their International Registration of 31 October 1958.

The use of origin sources is an important buyer tool for originating products of defined quality. Indications of origin of goods may be used for industrial and agricultural purposes to indicate the origin of goods and services. One use purpose is to facilitate trade through product information and should be accessible for use by all manufacturers in the area ${ }^{6}$. Due to its function of individualization, the geographical indication must distinguish from the mass of homogeneous goods the goods possessing special properties in comparison with those goods ${ }^{7}$.

Traditional state support for agricultural producers in many advanced market economies has led to the creation and establishment of a modern system of protection and protection of appellations of origin. On the other hand, in countries with low levels of agricultural production, the protection of the appellation of origin is at least premature. In many countries, it is difficult to install products whose place of origin indicates their particular quality. If these products are intended primarily for domestic consumption and are not competitive in foreign markets in terms of both quality and price, the protection of the names of their places of origin is not relevant, looks far-fetched and unnecessary. Thus, the protection of the name of the place of origin of the goods is mainly in the interest of foreign producers of agricultural and other similar products. This is not surprising, since the entire modern system of intellectual property of transition economies was originally created under the dictation of Western experts to protect the interests of their countries ${ }^{8}$.

Indication of origin of goods may be verbal, pictorial, appear as a national symbol, geographical map, etc. At the same time, the indication of the origin of goods should be distinguished from the common designations of goods of a particular type, which are not related to the specific place of their production, even though they contain the names of geographical features (for example, Kiev cake, Crimean wine) ${ }^{9}$.

\footnotetext{
${ }^{6}$ Солощук М., Капінос М., Лерантович Е. Право інтелектуальної власності на засоби індивідуалізації учасників цивільного обороту, товарів та послуг // Інтелектуальна власність. 2008. № 7. С. 54.

7 Комментарий к Четвертой части Гражданского кодекса Российской Федерации (постатейный). Правовое регулирование отношений в сфере интеллектуальной собственности. С постатейными материалами и практическими разъяснениями / под ред. И.А. Близнеца, А.Ю. Ларина. М. : Книжный мир, 2008. С. 521.

${ }^{8}$ Судариков С.А. Право интеллектуальной собственности: учебник. М. : Проспект, 2009. C. 257.

${ }^{9}$ Базилевич В.Д. Інтелектуальна власність: підручник. К. : Знання, 2006. С. 174.
} 
In Ukraine, the issues of acquisition, exercise and protection of intellectual property rights to geographical indications are regulated by Chapter 45 of the Civil Code of Ukraine and the Law of Ukraine "On Protection of the Rights to Indicate the Origin of Goods". Rules for drawing up, submission and examination of the application for registration of the qualified indication of origin of goods and / or the right to use the registered qualified indication of origin of goods, approved by the Order of the Ministry of Education and Science of Ukraine No. 598 of August 17, 2001, as amended.

In Ukraine today, dozens of indications of the origin of goods are registered as verbal or combined trademarks. Among them, in particular, the names of mineral waters "Truskavetska", "Naftusya", "Mirgorodskaya", "Morshynska", "Narzan". Some of them are even included in the relevant State Standards of Ukraine. Moreover, the trademarks of "Naftusia" have already been registered several by the name of manufacturers that have nothing to do with Truskavets "Naftusia". The uncontrolled use of these designations results in the erosion, loss of reputation, trust in this unique national heritage. Geographical indications serve to protect intangible values such as market differentiation, reputation and quality standards. They are also carriers of the cultural identity of the nation and the region.

In accordance with the provisions of the current legislation, the procedure for registration of geographical indications is defined ${ }^{10}$.

The term "geographical indication" is used in the TRIPS Agreement and EEC Regulation No 2081/92 of 14.07.92 "On the protection of geographical indications and names of places of origin of agricultural products and manufactured goods"; in addition, the term "indication of origin or the name of the place of origin "(Paris Convention for the Protection of Industrial Property)," the name of the place of origin "(Lisbon Agreement on the protection of designations of origin and their international registration)," $\mathrm{Al}$ origin "(Madrid Agreement Concerning sanctions for false and incorrect designation of origin products).

Types of geographical indication are the name of the place of origin of goods and indication of origin of goods. The name of the place of origin of the goods is the geographical name of the country, region, district or locality used to designate the originating product, the quality and specific characteristics of which are solely or substantially determined by the geographical environment of the place of origin, which may consist of natural or human factors, or both.

The indication of the place of origin of the goods is as follows:

- is the name of the geographical feature,

${ }^{10}$ Актуальні проблеми правового регулювання розвитку підприємницької діяльності в Україні: монографія / за ред. Н.М. Мироненко. Київ: підручники і посібники, 2008. С. 174. 
- the relationship of this name to specific, distinguished goods from the mass of homogeneous goods with special, unique properties;

- the relationship of this name to the specific natural conditions of the geographical feature and / or to any specific human factors that are unique to that geographical feature only;

- the dependence of the specific properties of the product on the specified specific natural conditions and / or human factors.

Indication of the place of origin of the goods is an indication which can take any form and which is used to refer to goods which have only a special reputation, due to their place of origin ${ }^{11}$.

The origin of a product is usually represented by the name of a country, geographic region, locality or object (including historical). For example, the designation "Made in the USSR" or "Made in China" indicate the country in which the goods are manufactured.

Names can be used together with the names of relevant geographical features. For example, products made in mountainous areas are often marked not only by names, but also by images of mountains and other objects. The packaging and the goods themselves are often labeled with an indication of their origin.

In current law, the term "indication of origin" covers the terms "simple indication of origin" and "qualified indication of origin", which in turn combines the terms "origin of goods" and "geographical indication of origin".

A simple indication of the origin of a commodity is any verbal or pictorial (graphic) designation that directly or indirectly indicates the geographical origin of the commodity, the legal protection of which is granted on the basis of its use ${ }^{12}$.

Qualified indication of origin of goods includes such concepts as "name of place of origin" and "geographical indication of origin". Legal protection of the qualified place of origin of the goods is granted on the basis of registration of intellectual property rights to it, which is valid indefinitely from the date of its registration.

The name of the place of origin of the goods is the name of the geographical place, which is used as a designation in the name of the product, which originates from the specified geographical place and has special properties, exclusively or mainly due to the natural conditions specific to that

11 Комментарий к Четвертой части Гражданского кодекса Российской Федерации (постатейный). Правовое регулирование отношений в сфере интеллектуальной собственности. С постатейными материалами и практическими разъяснениями / под ред. И.А. Близнеца, А.Ю. Ларина. М. : Книжный мир, 2008. С. 522.

12 Судариков С.А. Право интеллектуальной собственности: учебник. М. : Проспект, 2009. C. 256. 
geographical place (specific climate, soil composition, terrain, altitude, composition, water temperature, etc.), or a combination of these natural conditions with a specific human factor.

Geographical Indication of the Origin of a Product is the name of a geographical place, used as a designation in the name of a product originating from that geographical place and having certain qualities, reputation or other characteristics, predominantly due to the natural conditions or human factor or combination of these natural features that are characteristic of that geographical place. conditions and the human factor.

The distinction between place of origin and geographical indication of origin is made by three criteria. First, the name of the place of origin of the goods will be only if the product has special properties, and the geographical indication when the product has certain qualities, reputation or other characteristics.

Secondly, the name of the place of origin is a requirement that the properties of the goods are solely or mainly due to nature and the human factor. That is, for the name of the place of origin, the dependence of the special characteristics of the goods on the natural conditions of the place of origin of the goods is obligatory: although the specific properties of the goods designated by this name may depend on the human factor characteristic of the place, but necessarily in combination with natural conditions. (i.e. using local raw materials, climatic conditions, minerals, etc.).

Geographical indication of origin in the same context uses the term "primary", meaning less rigid communication. In this case, the particular characteristics, quality and reputation may depend on both natural and human factors, and may also be conditioned by the combination of natural conditions and professional experience, traditions and ethnographic features characteristic of the locality.

Thirdly, the production and processing of the goods indicated by the place of origin are carried out within the specified and geographical place, and for the geographical indication of origin it is sufficient that at least the main component of the goods designated by that name is produced or processed within the specified geographical place. Therefore, for the geographical indication of origin, raw materials can be imported from other regions and subjected to substantial processing sufficient to give the characteristics of the finished product ${ }^{13}$.

Having analyzed the provisions of the current Law of Ukraine "On Protection of the Rights to Indicate the Origin of Goods"14, we can

${ }^{13}$ Право інтелектуальної власності: акад. курс: підр. для студ. вищих навч. закладів / за ред. О. П. Орлюк, О. Д. Святоцького. К. : Видавничий дім “Ін Юре”, 2007. С. 437.

${ }^{14}$ Про охорону прав на зазначення походження товарів: Закон України від 16.06.2009 p. № 752-XIV // Відомості Верховної Ради України. 1999. № 32 від 13.08.99 р. Ст. 267. 
conclude that the intellectual property right to a geographical indication is granted provided that:

- it is the name of the geographical place from which the product originates;

- it is used as the name of such a product or as an integral part of that name;

- there are objectively specific natural conditions and / or human factors in the geographical area designated by this name, which give the product special properties or certain qualities;

- the goods marked with this name have the appropriate properties or certain qualities, which are solely or mainly due to the natural conditions specific to a particular geographical location or the combination of these conditions with a human factor characteristic of that geographical place;

- the production (extraction) and processing of a product or its part designated by this name is carried out within the specified geographical place. In order to obtain the intellectual property right for a geographical indication, the person entitled to that right submits an application for registration of this right to the Civil Service, where an examination of the application is carried out, upon which the applicant is issued a certificate of registration of the intellectual property right for the geographical indication. As already mentioned, the intellectual property right to geographical indication arises from the date of its state registration ${ }^{15}$.

As a rule, they are determined by the specific natural conditions of the geographical environment (Krasnodar Tea, Nizhyn Cucumbers, etc.) and (or) the professional experience and traditions of production of persons who produce goods and live in the area (for example, Khokhloma or Petryk painting, Tula gingerbread). Finally, the name of the place of origin of the goods becomes an independent object of legal protection only when the intellectual property right to it in the manner prescribed by law is registered with the Civil Service. In this capacity, the name of the place of origin of the goods is no different from other objects of intellectual property rights that are acquired by users only from the moment of their state registration.

The Law of Ukraine "On Protection of the Rights to Indicate the Origin of Goods" does not provide legal protection to a qualified indication of the origin of the goods that:

- does not meet the conditions stipulated in Article 7 of the Law of Ukraine "On Protection of the Rights to Indicate the Origin of Goods";

15 Право інтелектуальної власності: науково-практичний коментар до Цивільного кодексу України / за заг. ред. М.В. Паладія, Н.М. Мироненко, В.О. Жарова. К. : Парламентське видавництво, 2006. С. 330-331. 
- contrary to public order, the principles of humanity and morality;

- is the specific name of the product;

- correctly indicates the geographical place of manufacture of the goods, but creates a consumer misconception that the goods are manufactured in another geographical place;

- is the name of a plant or animal species and is therefore liable to mislead consumers as to the true origin of the product;

- is identical or similar in that it can be confused with a mark for goods and services, the rights of which are recognized in Ukraine, if, given the reputation, reputation and duration of use of such mark, such legal protection may mislead consumers as to the identity of the goods.

The Law of Ukraine "On Protection of Rights to Indicate the Origin of Goods" does not provide legal protection for a qualified indication of the origin of a commodity associated with a geographical place in a foreign country, if the rights to that indication or other designation, which in its content correspond to the notion of qualified indication of origin of goods, are not protected in the appropriate foreign country.

In the legal literature distinguish the following types of cities names of goods.

Depending on the circumstances that caused the specific properties of the product: formed under the influence of natural conditions; formed under the influence of human factors; combined species: formed under the influence of natural and human factors.

Depending on the area of distribution: national; international (international).

Depending on the degree of control by the relevant state bodies for the presence of special properties and production of goods: ordinary, which is characterized by the formation of the natural specific properties of the goods, which are individualized only under the influence of the natural environment or similar factors; regulated, which is characterized by the preliminary regulation of specific properties of the goods, while controlling the final stage of production; controlled (guaranteed), which is inherent in the control at all stages of production of the product, which is individualized by them, which makes such names especially valuable ${ }^{16}$.

The main functions of naming the place of origin (geographical indication) are as follows:

- distinctive character, which consists in the isolation of goods among the mass of homogeneous goods as having special quality, specific properties;

${ }^{16}$ Гульбин Ю.Т. Исключительные права на средства индивидуализации товаров товарные знаки, знаки обслуживания, наименования мест происхождения товаров: гражданско-правовой аспект. М. : Статут 2007. С. 110-111. 
- qualitative or guarantee, which is to guarantee the special quality, specific properties of the goods and is a condition for providing geographical indication of legal protection;

- information, which is manifested in the true indication of the place of manufacture of the goods;

- protective, which is to protect against counterfeiting, since no one except the legal user has the right to use the geographical indication.

One of the main differences between these means of individualisation is that, in respect of a trade mark, the right of use and the right of disposal may belong to one person, whereas in respect of geographical indication these rights may never belong to one person.

Geographical indication is often included as a trademark or security element. It may be registered as a trademark or part of it if the future trademark holder has the right to use the geographical indication. Examples are use as a trademark or part of a geographical indication that is perceived as fantastic for a particular product, use as a trademark or part of a little-known geographical area names with the addition or change of suffixes, prefixes and endings, use of the name of a known geographical area in adjective for a particular product, when such use of a geographical indication is a trademark security feature, use of the geographical indication I view as an adjective neohoronyuvalnoho element of the mark ${ }^{17}$.

The Law of Ukraine "On Protection of the Rights to Indicate the Origin of Goods" defines a range of intellectual property rights entities for a geographical indication, without specifying an exclusive list of intellectual property rights entities for a geographical indication, but only naming among them producers of goods and consumer associations.

According to Art. 9 of the Law of Ukraine "On Protection of Rights to Indicate the Origin of Goods", the right to register a qualified indication of the origin of the goods are: a person or group of persons who produce the product in the declared geographical location, special features, certain qualities, reputation or other characteristics of which are associated with that geographical location; consumer associations; institutions directly relevant to the production or study of relevant products, products, processes or geographical locations.

The above entities have the right to apply to the State Service for registration of a qualified indication of origin of goods. Qualified designation of origin may also include other persons who wish to use a registered place of origin or a registered geographical indication of origin. The right to use the

17 Клименко Л. Проблемы использования географических названий в маркировке товара // Право и экономика. 1999. № 9. С. 16. 
registered name of the place of origin of the goods or the registered geographical indication of the origin of the goods, provided that this right is registered, is made by manufacturers who, in the geographical place indicated in the Register, produce the goods, special properties, certain qualities or other characteristics of which correspond to those entered. to the Register.

The right to use a geographical indication is not the exclusive right of the holder of the certificate attesting to that right. Indeed, according to Article 17, paragraph 2 of the Law of Ukraine "On Protection of the Right to Indicate the Origin of Goods", according to which the registration of the right to use a qualified indication of the origin of the goods does not restrict the rights of other persons to register their rights to use $i^{18}$.

An applicant for the registration of a qualified indication of the origin of a product may be any natural or legal person who intends to produce a product with characteristics specific to a given geographical feature or is already producing the specified product. A person who registers in his own name a qualified indication of the origin of the goods shall be entitled to use them if the goods manufactured by him meet the requirements set out in the application for registration.

Thus, the Law of Ukraine "On Protection of Rights to Indicate the Origin of Goods" defines the subjects of intellectual property rights for a geographical indication by linking the registration of the intellectual property right to the geographical indication and the right to use the geographical indication, the intellectual property right of which is already registered. Persons who are legally entitled to such rights are subject to geographical indication intellectual property rights.

In order to obtain a certificate for the right to use a geographical indication, the manufacturer must submit an application to the State Service, which is executed accordingly ${ }^{19}$. The Civil Service within the specified time limits the examination of the application, which includes the examination of the conformity of the properties of the goods to the features established for goods for which a geographical indication may be used. Based on the results of the examination, the applicant is issued with or is not issued a certificate of the right to use the geographical indication and the data on it enter the names of places of origin and geographical indications of origin of the goods and the rights to use the registered qualified indications of origin of goods in the State Register of Ukraine.

${ }^{18}$ Глухівський Л. Про стан правової охорони зазначень походження товарів в Україні // Інтелектуальна власність. 2007. № 1. С. 19-20.

${ }^{19}$ Про затвердження Правил складання, подання та проведення експертизи заяви на реєстрацію кваліфікованого зазначення походження товару та/або права на використання зареєстрованого кваліфікованого зазначення походження товару: Наказ МОН від 17.08.2001 р. № 598 // Офіційний Вісник України 2001 № 36 від 21.09.2001 р. Ст. 1682. 
The holder of the certificate has the right to affix, along with a qualified indication of the origin of the goods, a warning mark to indicate that this indication is registered in Ukraine. The oval abbreviation (NMP) is used for the warning marking of the name of the place of origin of the goods. Instead, the marking may or may be accompanied by the text: "Name of origin of the goods registered in Ukraine". The oval abbreviation (GZP) is used for the warning marking of the geographical indication of the origin of the goods. Instead, the marking may or may be accompanied by the text: "Geographical indication of origin of goods registered in Ukraine"20.

Any holder of a right to use a geographical indication is entitled to counteract the illegal use of a geographical indication. Nothing prohibits manufacturers from a particular area from joining together to increase the effectiveness of their rights protection, but any manufacturer who has a certificate of use of a geographical indication has the full right not to participate in such association and use the geographical indication on his discretion (usually in compliance with legal requirements). The features of the right to use geographical indications determine the content of the obligations of the certificate holder to the right to use geographical indications, which are not borne by other subjects of intellectual property rights for this means of individualization of goods ${ }^{21}$.

\section{CONCLUSIONS}

The obligations of the holder of the certificate to use the geographical indication are laid down in Article 17, paragraph 7, and in Article 18 of the Law of Ukraine "On Protection of the Rights to Indicate the Origin of Goods", according to which the following are included. First, it is the duty to ensure that the quality, specific properties and characteristics of the product being manufactured are consistent with their description in the State Register. Second, there is an obligation not to prevent the specially authorized bodies from controlling the presence in the product of special features and other characteristics on the basis of which the geographical indication of the goods and / or the right to use them is registered. Third, the obligation to refrain from licensing geographical indications.

The validity of the intellectual property right to geographical indication is indefinite in accordance with Article 504 of the Civil Code of Ukraine. First of all, it should be noted that only one intellectual property right on a

\footnotetext{
${ }^{20}$ Глухівський Л. Про стан правової охорони зазначень походження товарів в Україні // Інтелектуальна власність. 2007. № 1. С. 20-21.

21 Орлюк О. Зазначення походження товарів як об'єкт правового регулювання // Юридичний радник. 2005. № 5. С. 31.
} 
geographical indication can have a validity period - the right to use a geographical indication; other rights cannot, in fact, be limited in time. Therefore, it can be concluded that the provisions of Article 504 of the Civil Code of Ukraine relate only to the right to use a geographical indication.

Pursuant to Article 15, paragraph 4, of the Law of Ukraine "On Protection of the Right to Indicate the Origin of Goods", the certificate's validity for the right to use a geographical indication is established, not the term of the right to use the geographical indication itself. According to Article 15 of the Law, the term of the certificate may be extended for another 10 years on the basis of the statement of the holder of the certificate. The number of times the certificate was extended. It can be concluded that the right to use the geographical indication is indefinite provided that the certificate for the right to use the geographical indication is re-registered.

\section{SUMMARY}

The use of means of individualization is essential for the pursuit of economic activity. In addition to the distinctive function, the means of individualization are intended to inform consumers about the quality and source of origin of goods, services, as well as to promote goods and services. Means of individualization are important components of an entity's business reputation, since the opinion of consumers, competitors and other persons about an entity is associated, first and foremost, with individual designations.

The content of the term "individualization means" is not limited to these three intellectual property objects and covers many other designations used for identification in the field of civil legal relationships (name of individual, nickname, company name, state name, domain name, etc.).

The development of the global information network (Internet) has led to the expansion of the traditional list of individualized means of intellectual property by incorporating a new specific element, the domain name, into it. Vocabularies used to address information resources on the Internet and identify goods and services, their manufacturer or geographical location cause a high likelihood of conflicts between owners of domain names, trademarks, business names, and geographical indications.

\section{REFERENCES}

1. Коссак В. М., Якубіський І.С. Право інтелектуальної власності: підручник. К. : Істина, 2007. С. 78.

2. Козлова О., Ковач Ж. Деякі проблеми правового регулювання комерційних найменувань в Україні у контексті міжнародно-правового досвіду // Промислова власність в Україні: проблеми правової охорони: 
зб. наук. статей / за ред. Ю.С. Шемшученка, Ю.Л. Бошицького. К.: Ін-т держави і права ім. В.М. Корецького НАН України, 2004. С. 326.

3. Сергеев А.П. Право интеллектуальной собственности. М. : Теис, 1996. C. 524.

4. Козлова О., Ковач Ж. Деякі проблеми правового регулювання комерційних найменувань в Україні у контексті міжнародно-правового досвіду // Промислова власність в Україні: проблеми правової охорони: зб. наук. статей / за ред. Ю.С. Шемшученка, Ю.Л. Бошицького. К.: Ін-т держави і права ім. В.М. Корецького НАН України, 2004. С. 326.

5. Паладій М.В. Право інтелектуальної власності на комерційне найменування // Правова охорона комерційних позначень в Україні: проблеми теорії і практики: зб. наук. статей / за заг. ред. Ю.С. Шемшученка, Ю.Л. Бошицького. К. : “Юридична думка”, 2006. С. 372.

6. Солощук М., Капінос М., Лерантович Е. Право інтелектуальної власності на засоби індивідуалізації учасників цивільного обороту, товарів та послуг // Інтелектуальна власність. 2008. № 7. С. 54.

7. Комментарий к Четвертой части Гражданского кодекса Российской Федерации (постатейный). Правовое регулирование отношений в сфере интеллектуальной собственности. С постатейными материалами и практическими разъяснениями / под ред. И.А. Близнеца, А.Ю. Ларина. М. : Книжный мир, 2008. С. 521.

8. Судариков С.А. Право интеллектуальной собственности: учебник М. : Проспект, 2009. С. 257.

9. Базилевич В.Д. Інтелектуальна власність: підручник. К. : Знання, 2006. С. 174.

10. Актуальні проблеми правового регулювання розвитку підприємницької діяльності в Україні: монографія / за ред. Н.М. Мироненко. Київ: підручники і посібники, 2008. С. 174.

11. Комментарий к Четвертой части Гражданского кодекса Российской Федерации (постатейный). Правовое регулирование отношений в сфере интеллектуальной собственности. С постатейными материалами и практическими разъяснениями / под ред. И.А. Близнеца, А.Ю. Ларина. М. : Книжный мир, 2008. С. 522.

12. Судариков С.А. Право интеллектуальной собственности: учебник. М. : Проспект, 2009. С. 256.

13. Право інтелектуальної власності: акад. курс: підр. для студ. вищих навч. закладів / за ред. О.П. Орлюк, О.Д. Святоцького. К. : Видавничий дім “Ін Юре”, 2007. С. 437.

14.Про охорону прав на зазначення походження товарів: Закон України від 16.06.2009 р. № 752-XIV // Відомості Верховної Ради України. 1999. № 32 від 13.08.99 р. Ст. 267. 
15. Право інтелектуальної власності: Науково-практичний коментар до Цивільного кодексу України / за заг. ред. М.В. Паладія, Н.М. Мироненко, В.О. Жарова. К. : Парламентське видавництво, 2006. C. 330-331.

16. Гульбин Ю.Т. Исключительные права на средства индивидуализации товаров - товарные знаки, знаки обслуживания, наименования мест происхождения товаров: гражданско-правовой аспект M. : Статут 2007. С. 110-111.

17. Клименко Л. Проблемы использования географических названий в маркировке товара // Право и экономика. 1999. № 9. С. 16.

18. Глухівський Л. Про стан правової охорони зазначень походження товарів в Україні // Інтелектуальна власність. 2007. № 1. С. 19-20.

19. Про затвердження Правил складання, подання та проведення експертизи заяви на реєстрацію кваліфікованого зазначення походження товару та/або права на використання зареєстрованого кваліфікованого зазначення походження товару: Наказ Міністерства освіти і науки України від 17.08.2001 р. № 598 // Офіційний Вісник України 2001. № 36 від 21.09.2001 р. Ст. 1682.

20. Глухівський Л. Про стан правової охорони зазначень походження товарів в Україні // Інтелектуальна власність. 2007. № 1. С. 20-21.

21. Орлюк О. Зазначення походження товарів як об'єкт правового регулювання // Юридичний радник. 2005. № 5 (7). С. 31.

Information about the author: Mazurenko S. V., $\mathrm{PhD}$ in Law, Associated Professor at the Department of Intellectual Property Law, National University "Odessa Law Academy" 2, Academychna str., Odessa, 65009, Ukraine 